\title{
Grid Integration of Offshore Wind Farms Using Modular Marx Multilevel Converters
}

\author{
Luís Encarnação ${ }^{1}$, José Fernando Silva ${ }^{2}$, Sónia F. Pinto ${ }^{2}$, and Luis M. Redondo ${ }^{1}$ \\ ${ }^{1}$ Instituto Superior de Engenharia de Lisboa, Cie3, Portugal \\ \{luisrocha, lmredondo\} @deea.isel.pt \\ ${ }^{2}$ Instituto Superior Técnico, Cie3, TU Lisbon, Portugal \\ fernandos@alfa.ist.utl.pt, soniafp@ist.utl.pt
}

\begin{abstract}
This paper proposes the use of a Modular Marx Multilevel Converter, as a solution for energy integration between an offshore Wind Farm and the power grid network. The Marx modular multilevel converter is based on the Marx generator, and solves two typical problems in this type of multilevel topologies: modularity and dc capacitor voltage balancing. This paper details the strategy for dc capacitor voltage equalization. The dynamic models of the converter and power grid are presented in order to design the converter ac output voltages and the dc capacitor voltage controller. The average current control is presented and used for power flow control, harmonics and reactive power compensation. Simulation results are presented in order to show the effectiveness of the proposed $\mathrm{M}^{3} \mathrm{C}$ topology.
\end{abstract}

Keywords: modular multilevel converter, offshore wind farm, dc capacitor voltage equalization.

\section{Introduction}

The multilevel conversion of electric energy is appropriate for high levels of voltage and current, and therefore suitable for power and energy systems applications. The technology for the energy transmission system between wind farm and onshore grid can be done using ac connection (High Voltage Alternating Current - HVAC) or dc connection (High Voltage Direct Current - HVDC) [1]. This paper uses dc connection (HVDC - VSC voltage source converter) and proposes a three-phase modular multilevel Marx converter $\left(3 \mathrm{M}^{3} \mathrm{C}\right)$, with five levels for each phase leg, to connect the $\mathrm{dc}$ wind farm to the inshore power electrical network. The modular multilevel converter is based on the Marx generator $\left(\mathrm{M}^{3} \mathrm{C}\right)[2,3,4]$ and solves two typical problems with known multilevel converter topologies [5,6], such as the Neutral-Point Clamped (NPC) and flying capacitor (FC). These topologies are non modular being difficult to balance the dc capacitor voltages, for topologies with levels higher than three. The five-level multilevel converter leg topology uses 8 basic cells for each arm ( 4 cells for each half arm). The three-phase 5 level multilevel converter uses 24 basic cells $(3 \times 8)$, and each basic cell has a capacitor which will be charged with $U_{C i}=U_{d c} /(n-$ 1 ), where $n$ represents the number of levels (in this case $n=5$, implying $U_{C i}=U_{d c} / 4$ ). 
Section 2 presents the technological contribution of this paper to value creation. In Section 3 , the $3 \mathrm{M}^{3} \mathrm{C}$ with five levels for each phase leg is presented. The dynamic models of the converter and power grid are presented in Section 4 , in order to obtain the converter ac output voltages for a linear three-phase inductive load, and the dc capacitor voltage controller. The average current control $[7,8]$ is presented and used for power flow control, harmonics and reactive power compensation. A sigma-delta modulator is applied to a $\mathrm{M}^{3} \mathrm{C}$ leg, and a sliding-mode approach [9] is used to enforce the converter ac output voltages. The strategy for dc capacitor voltage equalization is presented with a detailed implementation of the algorithm. Simulation results are presented in Section 5 to show the effectiveness of the proposed solution.

\section{Contribution to Value Creation}

This paper proposes a solution for energy integration between an offshore Wind Farm and the power grid network, using a three-phase $\mathrm{M}^{3} \mathrm{C}$ with five levels for each converter arm. The solution presented enables cleaner electrical energy because it uses controllers to reactive power and harmonic compensation. This work will contribute to value creation as it also allows a better use of renewable energy and the development of new technologies to enhance economic activity, creating more labor, more jobs while showing the potential to reduce; 1) the price per kilowatt, 2) the costs of imported fossil fuels and 3) the carbon dioxide emissions.

\section{Three-Phase Modular Multilevel Marx Converter $3 \mathbf{M}^{3} \mathrm{C}$}

Three-phase modular multilevel Marx converter $\left(3 \mathrm{M}^{3} \mathrm{C}\right)$ with five levels for each leg is described. The proposed modular converter is based on Marx generators and uses $\mathrm{M}^{3} \mathrm{C}$ topology (Fig. 1a). Its operation is described in detail in [2]. This topology has three bi-directional switches $\left(S_{\mathrm{k}} D_{\mathrm{k}}, S_{\mathrm{ka}} D_{\mathrm{ka}}\right.$ and $\left.S_{\mathrm{k} \mathrm{k}+1} D_{\mathrm{k} \mathrm{k}+1}\right)$ and a capacitor denoted $C_{\mathrm{k}}$ that will be charged with $U_{\mathrm{Ck}}=U_{\mathrm{dc}} /(n-1)$, where $n=5$, implying $U_{C k}=U_{d c} / 4$, and $\mathrm{k}$ represents the number of $\mathrm{M}^{3} \mathrm{C}$ cells or modules. The strategy to equalize all $C_{\mathrm{k}}$ capacitors will be explained in Section 4.4.

With the basic $\mathrm{M}^{3} \mathrm{C}$ cell, $\mathrm{n}$ levels MCs can be obtained, using $\mathrm{n}-1$ basic cells for the upper arm, and n-1 cells for the bottom arm. The five-level MC leg topology uses four basic cells (Fig. 1b) for each half arm, with a total of 8 cells for each converter arm (or phase). A three-phase $3 \mathrm{M}^{3} \mathrm{C}$ with five levels for each phase uses twenty four basic cells (Fig. 1b). To understand the operating principles of three-phase $\mathrm{M}^{3} \mathrm{C}$, consider the five-level leg in which, to verify Kirchhoff's laws, (n-1) basic cells must present the voltage $U_{\mathrm{dc}} /(n-1)$. Table 1 show all possible combinations with the basic cells (bottom and top arm) to have 4 basic cells turned off ( $S_{\mathrm{Ka}}$ on) and 4 turned on $\left(S_{\mathrm{K}}\right.$ on) and the corresponding voltage levels on each arm.

Table 1 shows the five voltage levels of voltage $U_{\text {Load }}$ and the number of vectors for each level (there are 36 redundant vectors in level 3 ). 


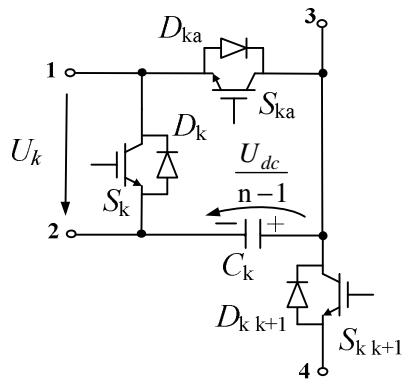

(a)

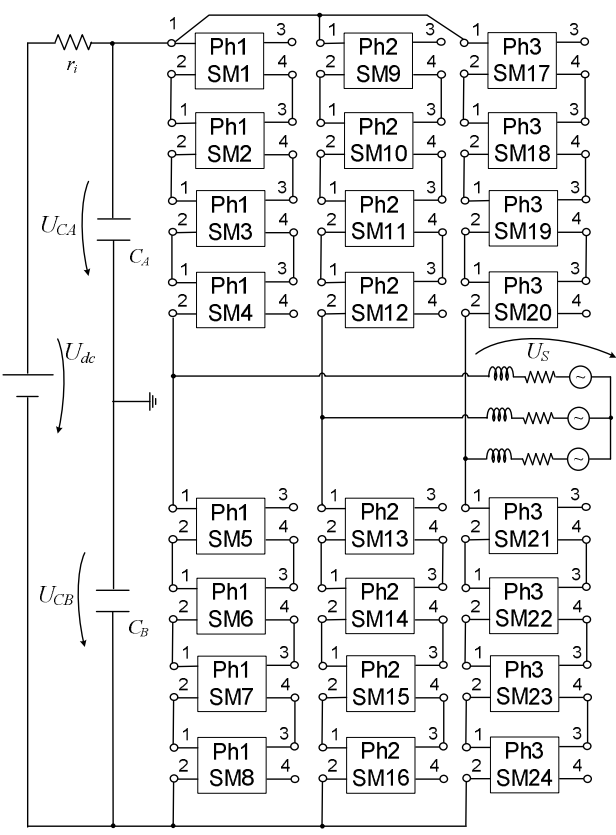

(b)

Fig. 1. Modular Multilevel Marx Converter topology: a) Structure of the basic cell; b) Three-phase $\mathrm{M}^{3} \mathrm{C}$ with five levels for each phase leg $(\mathrm{Ph} \rightarrow$ phase $\mathrm{SM} \rightarrow$ sub-module cell)

Table 1. Voltage levels and number of vectors for a Five-Level $\mathrm{M}^{3} \mathrm{C}$ leg

\begin{tabular}{|c|c|c|c|c|}
\hline Level & $U_{\text {Load }}$ & $\begin{array}{c}\text { Number } \\
\text { Upper }\end{array}$ & $\begin{array}{l}\text { ON Cells } \\
\text { Bottom }\end{array}$ & Number of Vectors \\
\hline 1 & $-U_{d c} / 2$ & 0 & 4 & $1 \times 1=1$ \\
\hline 2 & $-U_{d c} / 4$ & 1 & 3 & $4 \times 4=16$ \\
\hline 3 & 0 & 2 & 2 & $6 \times 6=36$ \\
\hline 4 & $+U_{d c} / 4$ & 3 & 1 & $4 \times 4=16$ \\
\hline 5 & $+U_{d c} / 2$ & 4 & 0 & $1 \times 1=1$ \\
\hline
\end{tabular}

\section{$4 \quad$ Modeling and Controller Design of $\mathrm{M}^{3} \mathrm{C}$ Connection to Inshore Network}

The dynamic models of the dc offshore fed $\mathrm{M}^{3} \mathrm{C}$ to the inshore ac network are obtained in this section, together with the average current control used for power flow, harmonic and reactive power compensation. The strategy to equalize all the capacitors voltages is presented with a detailed implementation of the Vector Decision algorithm. 


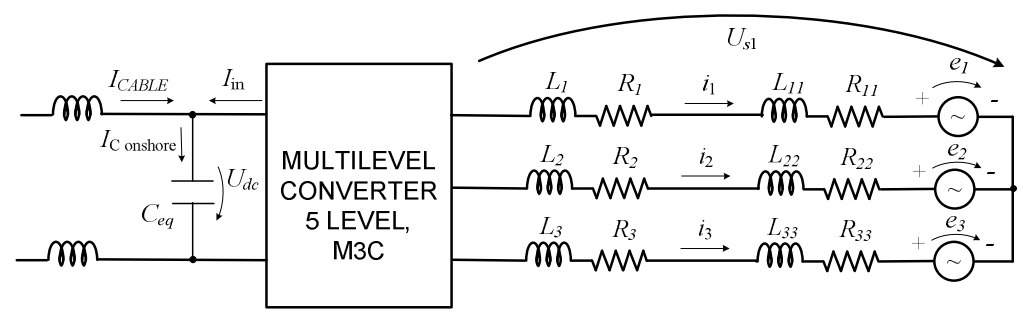

Fig. 2. Electrical diagram of offshore de fed $M^{3} C$ to the inshore ac network

\subsection{Modeling the $\mathrm{M}^{3} \mathrm{C}$ Connection to Inshore AC Network}

The ac side model (Fig. 2) in system coordinates (123) can be obtained using the Kirchhoff voltage and current laws, considering $R_{1}=R_{2}=R_{3}$ and $R_{11}=R_{22}=R_{33}$ and $L_{1}=L_{2}=L_{3}$ and $L_{11}=L_{22}=L_{33}$ then $R_{e q}=R_{1}+R_{11}$ and $L_{e q}=L_{1}+L_{11}$ :

$$
\left\{\begin{array}{l}
U_{S 1}=R_{e q} i_{1}+L_{e q} \frac{d i_{1}}{d t}+e_{1} \\
U_{S 2}=R_{e q} i_{2}+L_{e q} \frac{d i_{2}}{d t}+e_{2} \\
U_{S 3}=R_{e q} i_{3}+L_{e q} \frac{d i_{3}}{d t}+e_{3}
\end{array}\right.
$$

The system model in dq0 coordinates (2) can be obtained applying Park's transformation to (1). The average current control method uses this state-space model (2) for power flow control, harmonics and reactive power compensation.

$$
\left\{\begin{array}{l}
\frac{d i_{d}}{d t}=-\frac{R_{e q}}{L_{e q}} i_{d}+\frac{1}{L_{e q}}\left(L_{e q} \omega i_{q}+u_{d}-e_{d}\right) \\
\frac{d i_{q}}{d t}=-\frac{R_{e q}}{L_{e q}} i_{q}+\frac{1}{L_{e q}}\left(-L_{e q} \omega i_{d}+u_{q}-e_{q}\right)
\end{array}\right.
$$

\subsection{Linear Control of the $U_{d c}$ Voltage}

This section presents the dc capacitor voltage controller (Fig. 1b). The linear control of the $U_{d c}$ voltage provides the $i_{d r e f}$ component which in turn will be used to enforce the converter ac output voltages references. The controller is designed from the converter model (dc side) in dq0 coordinates (Fig. 3).

Considering $C e q=\frac{C_{A}}{2}=\frac{C_{B}}{2}=\frac{C}{2}$ and $U_{C A}=U_{C B}=\frac{U_{d c}}{2}$ the equivalent model of the converter and offshore farm is shown in Fig. 3, and from the circuit depicted the $U_{d c}$ voltage dynamics is:

$$
C_{e q} \frac{d U_{d c}}{d t}=I_{C A B L E}+\gamma_{d} I_{d}
$$




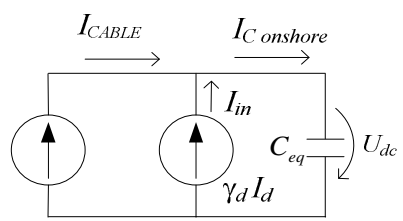

Fig. 3. Equivalent model of the converter DC side

Neglecting the pole associated to a small time delay $T_{d}$ in the current controlled current source $\gamma_{d} I_{d}$, the block diagram for the $U_{d c}$ control is shown in Fig. 4.

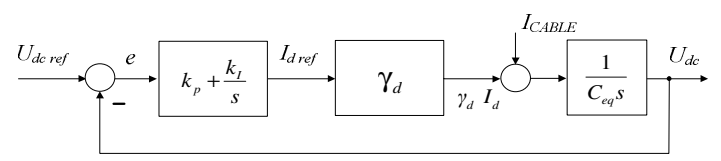

Fig. 4. Block diagram of the linear control of the $U_{d c}$ voltage

The transfer function results in a $2^{\text {nd }}$ order system (4) with a zero located in $-k_{I} / k_{P}$.

$$
\frac{U_{d c}(s)}{U_{d c ~ r e f}(s)}=\frac{\frac{k_{P} \gamma_{d}}{C_{e q}} s+\frac{k_{I} \gamma_{d}}{C_{e q}}}{s^{2}+\frac{k_{P} \gamma_{d}}{C_{e q}} s+\frac{k_{I} \gamma_{d}}{C_{e q}}}
$$

In order to obtain a fast response with reduced overshoot, the zero of the controller should obey $-k_{I} / k_{P} \leq-\xi \omega_{n}$, therefore the $C(\mathrm{~s})$ controller is designed for a damping factor $\xi=\sqrt{2} / 2$ and $\omega_{n}=2 \pi \times 25 \mathrm{rad}^{-1} \mathrm{~s}^{-1}\left(\omega_{n} \ll 2 \pi / T_{d}\right)$, the following relations hold:

$$
\left\{\begin{array} { l } 
{ 2 \xi \omega _ { n } = \frac { k _ { P } \gamma _ { d } } { C _ { e q } } } \\
{ \omega _ { n } { } ^ { 2 } = \frac { k _ { I } \gamma _ { d } } { C _ { e q } } }
\end{array} \Rightarrow \left\{\begin{array}{l}
k_{P}=\frac{2 \xi \omega_{n} C_{e q}}{\gamma_{d}} \\
k_{I}=\frac{\omega_{n}{ }^{2} C_{e q}}{\gamma_{d}}
\end{array}\right.\right.
$$

Using the $\mathrm{M}^{3} \mathrm{C}$ converter parameters, $C_{e q}=2 \mathrm{mF} ; \gamma_{d}=\frac{u_{d}}{U_{d c}}=\frac{100 \mathrm{kV}}{200 \mathrm{kV}}=0.5$ the PI parameters are $k_{I}=98.7$ and $k_{P}=0.9$.

\subsection{Linear Control of $i_{d}$ and $i_{q}$ Currents}

This section details the average current control of $i_{d}$ and $i_{q}$ currents. From the state-space model (2) in dq0 coordinates, making $H_{d}=L_{e q} \omega i_{q}+u_{d}-e_{d}$ and $H_{q}=-L_{e q} \omega i_{d}+u_{q}-e_{q}$ the linear model (6) is obtained. To obtain the control value $H_{d}$ we use a PI controller where $I_{d r e f}$ (set-point) is obtained from the output of the $U_{d c}$ voltage controller. To obtain $H_{q}$ another PI controller is used, with the set-point $I_{q r e f}=0$ to ensure reactive power compensation and harmonics mitigation. 


$$
\left\{\begin{array}{l}
\frac{d i_{d}}{d t}=-\frac{R_{e q}}{L_{e q}} i_{d}+\frac{H_{d}}{L_{e q}} \\
\frac{d i_{q}}{d t}=-\frac{R_{e q}}{L_{e q}} i_{q}+\frac{H_{q}}{L_{e q}}
\end{array}\right.
$$

Neglecting $R_{e q}$ the following block diagram was obtained (Fig. 5):

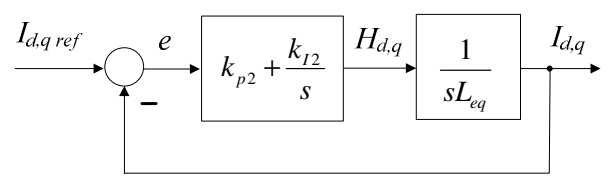

Fig. 5. Block diagram of the linear control of $I_{d}$

The resulting $2^{\text {nd }}$ order system with a zero enables the calculation of $k_{P 2}$ and $k_{I 2}$ :

$$
\left\{\begin{array} { l } 
{ 2 \xi _ { 2 } \omega _ { n 2 } = \frac { k _ { P 2 } } { L _ { e q } } } \\
{ \omega _ { n 2 } { } ^ { 2 } = \frac { k _ { I 2 } } { L _ { e q } } }
\end{array} \Rightarrow \left\{\begin{array}{l}
k_{P 2}=2 \xi_{2} \omega_{n 2} L_{e q} \\
k_{I 2}=\omega_{n 2}^{2} L_{e q}
\end{array}\right.\right.
$$

The PI controllers are also designed for a damping factor $\xi_{2}=\sqrt{2} / 2$ and $\omega_{n 2}=2 \pi \times 25$ rad.s ${ }^{-1}$. Considering $L_{e q}=L_{1}+L_{11}=32 \mathrm{mH}($

Fig. 2), the PI parameters are $k_{I 2}=789.6$ and $k_{P 2}=7.1$. Equations of $H_{d}$ and $H_{q}$ can be solved for $u_{d}$ and $u_{q}$ to obtain the ac output voltages (Fig. 6).

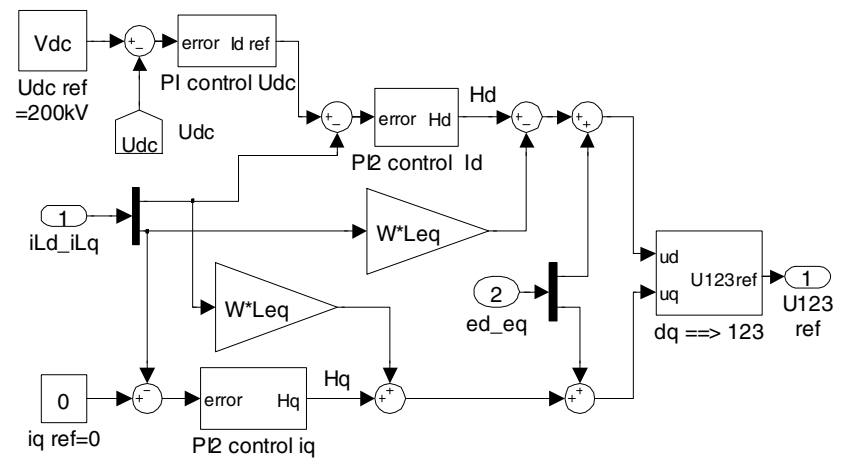

Fig. 6. Block diagram with average current control method to obtain the converter ac output voltages

Using inverse Park transformation three sinusoidal voltages references can be obtained from $u_{d}$ and $u_{q}$. Then these voltages are fed to three sigma-delta modulators to obtain the three converter ac output voltages in phase coordinates (Fig. 7). Each sigma-delta modulator uses the sliding-mode stability condition to ensure the desired 
voltage applied to the load by increasing or decreasing the chosen level. The modulator uses five levels, $u_{m k}\left( \pm 1 / 2 U_{d c}=100 \mathrm{kV}, \pm 1 / 4 U_{d c}=50 \mathrm{kV}\right.$ and $\left.0 \mathrm{~V}\right)$ to obtain the voltage output $U_{l}$.

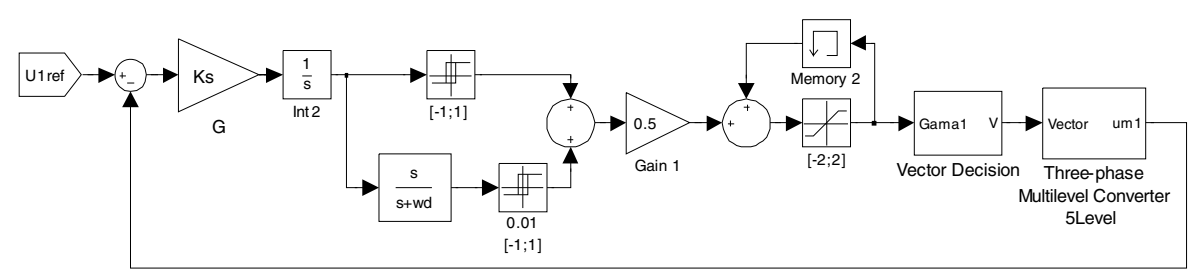

Fig. 7. Block diagram of sigma-delta modulator to obtain the converter ac output voltages

\subsection{Capacitor Voltage Balancing}

To balance all the capacitor voltages a Vector Decision algorithm was developed. This algorithm does not need data from the capacitor voltage measurements.

For three-level MC leg topology the algorithm is not necessary to balance the capacitors voltages, because the $S_{\mathrm{k} k+1}$ semiconductor of each basic cell (Fig. 1a) guarantees voltage balancing. However, for $\mathrm{M}^{3} \mathrm{C}$ with leg levels higher than three, a different strategy is needed. The idea of the Vector decision algorithm is to equally select the n-1 vectors of each intermediate level (2, 3 and 4), where $n$ represents the number of levels. To obtain the first $\left(-U_{d c} / 2\right)$ and the fifth voltage level $\left(+U_{d c} / 2\right)$, only one vector is available. Therefore, the control of each converter leg will use 14 vectors $(1+4+4+4+1)$ (Table 2). The Vector decision algorithm must use different cells (turned on) in the same level to perform capacitor voltage balancing. Since in the intermediate levels there are $(3 \times 4)$ redundant vectors a counter for each leg was devised as a function of the respective level (Table 2). The redundant vectors produce the same output voltage in the converter but different effects in the capacitors (charge or discharge). Table 2 shows the redundant vector choice (a, b, c, d) in states $-1,0,1$ to guarantee capacitor voltage balance.

The algorithm assigns a different vector for each leg as defined in table 2. The decision vector is chosen from the output status $C_{k}$ and the output of the sigma delta modulator, $\gamma_{\mathrm{k}}$ value. Each $\mathrm{C}_{\mathrm{k}}$ output depends on the status of three internal counters, one for each intermediate level $\left(C_{10} \Leftrightarrow \gamma_{-1}, C_{20} \Leftrightarrow \gamma_{0}, C_{30} \Leftrightarrow \gamma_{1}\right)$. This internals counters, reset to one after three increments, repeating the same sequential assignment for each cycle.

Table 2. Vector decision Table

\begin{tabular}{|c|c|c|c|c|c|}
\hline$C_{k}$ & -2 & -1 & 0 & 1 & 2 \\
\hline 0 & V1 & & & & V5 \\
\hline 1 & & $\mathrm{~V} 2 \mathrm{a}$ & V3a & $\mathrm{V} 4 \mathrm{a}$ & \\
\hline 2 & & $\mathrm{~V} 2 \mathrm{~b}$ & $\mathrm{~V} 3 \mathrm{~b}$ & $\mathrm{~V} 4 \mathrm{~b}$ & \\
\hline 3 & & $\mathrm{~V} 2 \mathrm{c}$ & $\mathrm{V} 3 \mathrm{c}$ & $\mathrm{V} 4 \mathrm{c}$ & \\
\hline 4 & & $\mathrm{~V} 2 \mathrm{~d}$ & V3d & V4d & \\
\hline
\end{tabular}




\section{Simulation Results}

The grid integration of an offshore wind farm using a modular Marx multilevel converter was simulated using MATLAB/Simulink environment in accordance with Fig. 8. These simulations illustrates the three-phase $\mathrm{M}^{3} \mathrm{C}$ operating as a multilevel inverter to deliver energy ( 3 sinusoidal output voltages with reference amplitude equal to $100 \mathrm{kV}$ ) from the offshore wind park (bipolar connection) to the power grid. The main circuit parameters (Fig. 1, Fig. 2 and Fig. 8) are $U_{d c}=200 \mathrm{kV}, C_{A}=C_{B}=4 \mathrm{mF}, 24$ Capacitor cell $C_{1-24}=400 \mu \mathrm{F}, R_{1}=0.33 \Omega, L_{1}=30 \mathrm{mH}, R_{11}=0.1 \Omega, L_{11}=2 \mathrm{mH}$.

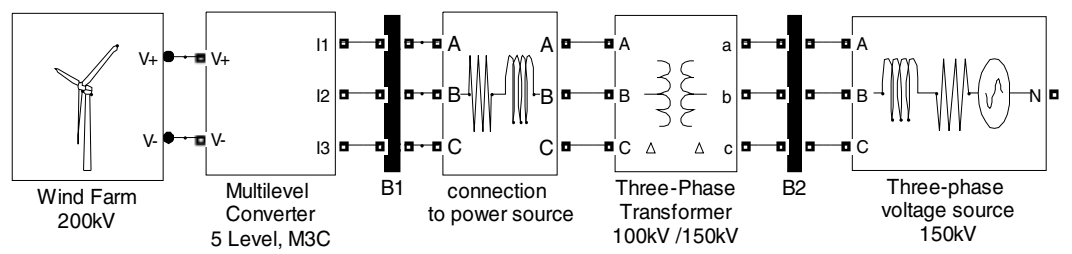

Fig. 8. Block diagram of the $\mathrm{dc}$ fed $\mathrm{M}^{3} \mathrm{C}$ Connection to Inshore ac Network

In order to verify the effectiveness of the proposed strategy power variations were simulated from offshore wind park (begin with 500A, then change to $700 \mathrm{~A}$ at $0.4 \mathrm{~s}$, and after to $800 \mathrm{~A}$ at $0.6 \mathrm{~s}$ and finally a step current to $1000 \mathrm{~A}$ at $0.8 \mathrm{~s}$. Fig. 9 shows the 8 capacitor voltages in arm 1 balanced within approximately $\pm 5 \%$ of their working voltage $(50 \mathrm{kV})$.
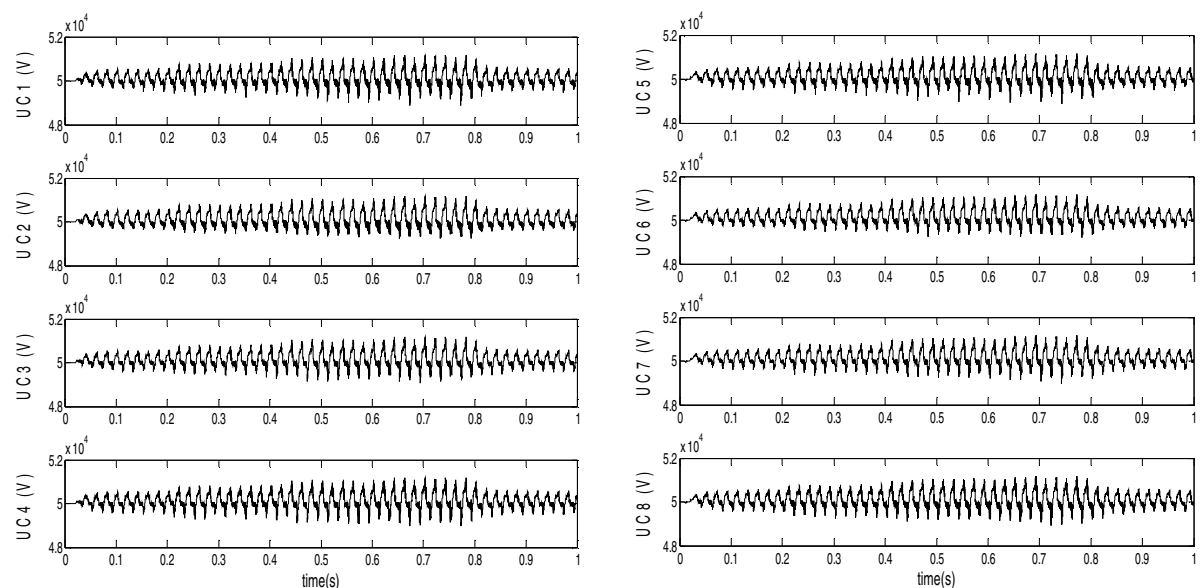

9a) Upper $\operatorname{Arm}\left(U_{1} U_{2} U_{3} U_{4}\right)$

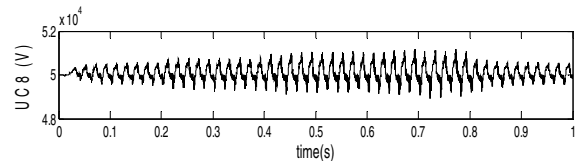

9b) Bottom $\operatorname{Arm}\left(U_{5} U_{6} U_{7} U_{8}\right)$

Fig. 9. Simulation results showing balanced capacitor voltages in arm 1 of $3 \mathrm{M}^{3} \mathrm{C}$ 

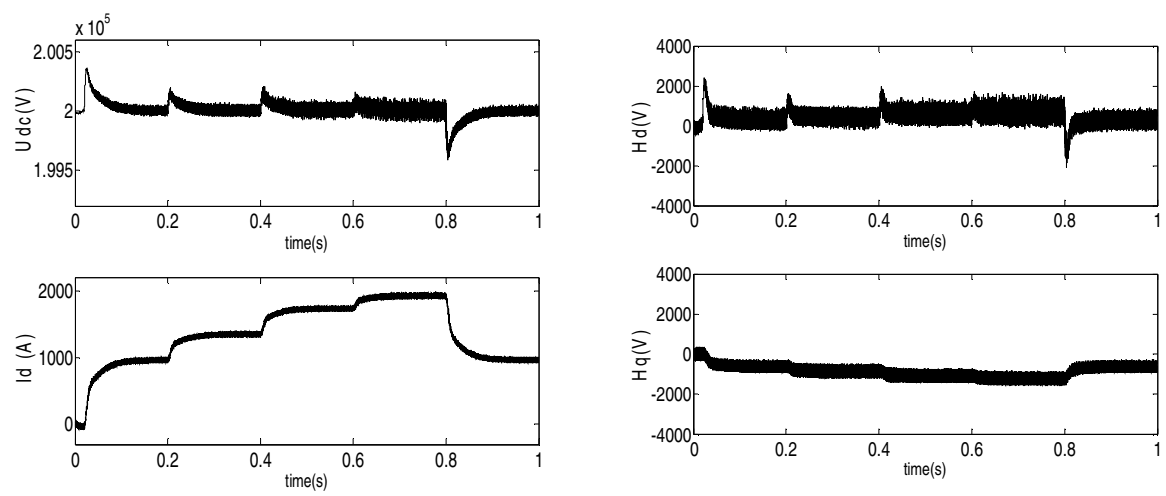

a)

b)

Fig. 10. Simulation results of linear control: a) $U_{d c}$ voltage and $I_{d}$ b) $H_{d}$ and $\mathrm{H}_{q}$

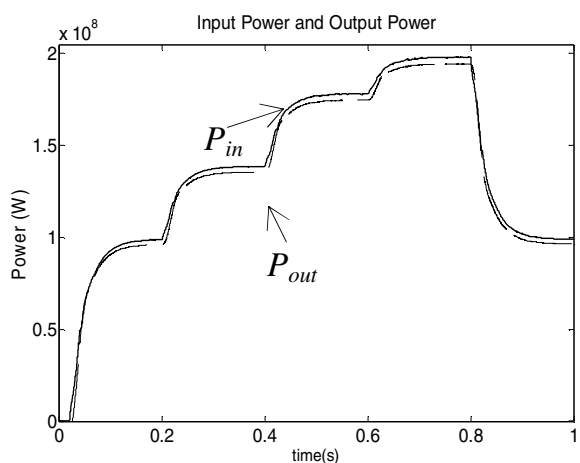

a)

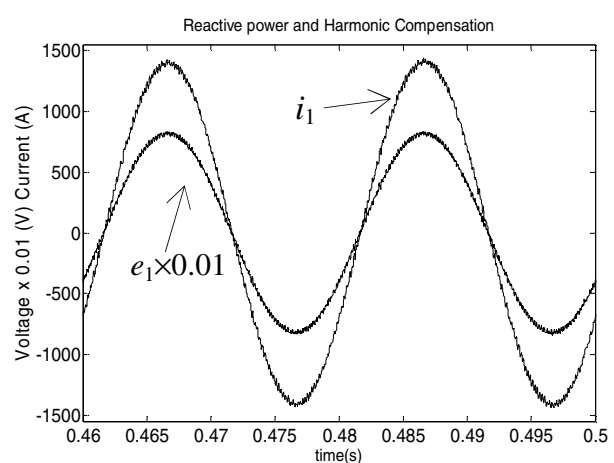

b)

Fig. 11. Simulation results a) Output and input powers b) Current and voltage $\times 0.01$ in phase 1

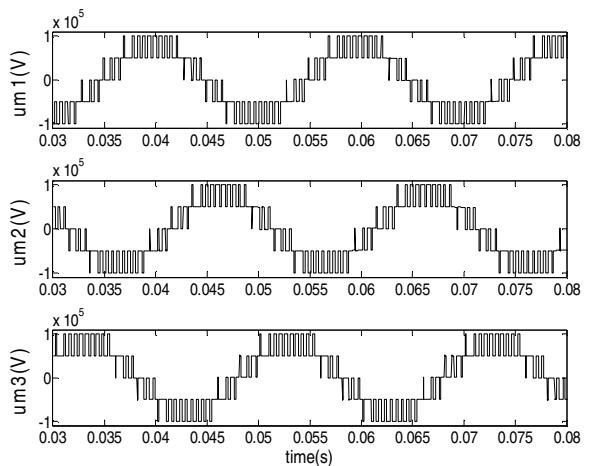

a)

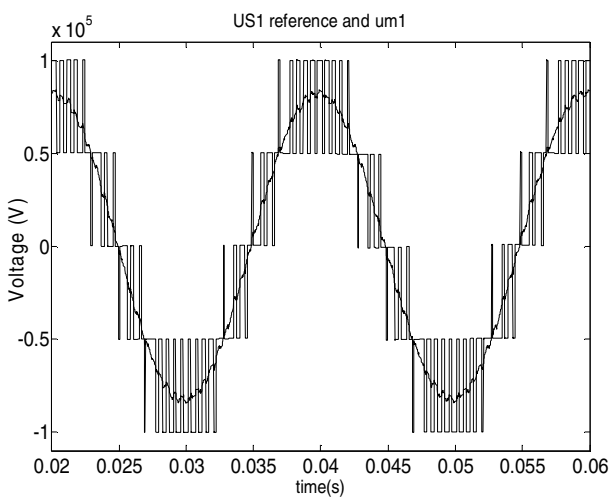

b)

Fig. 12. Simulation results a) Three-phase ac output voltages b) $U_{S 1 \text { ref }}$ and $u_{m 1}$ 
Fig. 10a shows the linear control of the $U_{d c}$ voltage (top left waveform) and the $2^{\text {nd }}$ waveform presents the $I_{d}$ control. The $1^{\text {st }}$ waveform (top right) of Fig. 10b shows the $H_{d}$ component and the $2^{\text {nd }}$ waveform presents $H_{q}$ component. Fig. 11 a presents input and output power figures to show the high efficiency of this power converter $(\approx 98 \%)$. Reactive power compensation is observed in Fig. 11b, in which the phase angle between current (in line 1) and voltage $(U s \times 0.01)$ (in phase 1) is zero. Fig. 12a show the three-phase converter ac output voltages $\left(u_{m 1}, u_{m 2}\right.$ and $\left.u_{m 3}\right)$. Fig. $12 \mathrm{~b}$ presents converter ac output voltage in phase 1 and sinusoidal output voltage reference $U_{\text {SIref }}$.

\section{Conclusions}

This paper has presented modular multilevel converter for connecting an offshore wind park to the inshore ac power grid network (HVDC-VSC). The three-phase modular multilevel Marx converter $\left(3 \mathrm{M}^{3} \mathrm{C}\right)$ has five levels in each arm.

The multilevel converter was built with modular MC cells that can be used to build multilevel converter with high number of levels. The capacitor voltage equalization is obtained with a strategy (Vector Decision algorithm) that does not need to measure the capacitor voltages. The dc link capacitor voltage control was designed using a linear controller. Sigma-delta modulators were used to obtain the converter ac output voltages, and average current control was used for power flow control, harmonics and reactive power compensation. Presented simulations have shown the effectiveness of the proposed strategy.

\section{References}

1. Adam, G.P., Anaya-Lara, O.G., Burt, M.J.: Comparison between Two VSC-HVDC Transmission Systems Technologies: modular and Neutral Point Clamped Multilevel Converter. In: 35th Annual Conference of the IEEE Industrial Electronics Society IECON Porto, Portugal (2009)

2. Encarnação, L., Silva, J.F., Pinto, S.F., Redondo, L.M.: A New Modular Marx Derived Multilevel Converter. In: 2nd Doctoral Conference on Computing Electrical and Industrial Systems - DoCEIS Costa da Caparica, Portugal (2011)

3. Lesnicar, A., Maruardt, R.: An Innovative Modular Multilevel Converter Topology Suitable for a Wide Power Range. In: IEEE Power Tech. Conference, Bologna, Italy (2003)

4. Redondo, L.M., Fernando, J.F.: Repetitive High-Voltage Solid-State Marx Modulator Design for Various Load Conditions. IEEE Transactions on Plasma Science 37(8), 16321637 (2009)

5. Franquelo, L.G., Rodríguez, J., Leon, J.I., Kouro, S.: The age of multilevel converters arrives. IEEE Industrial Electronics Magazine 2(2), 28-39 (2008)

6. Encarnação, L., Silva, J.F.: Reactive Power Compensation Using Sliding-Mode Controlled Three Phase Multilevel Converters. In: 12th International Conference on Harmonics and Quality of Power - ICHQP Cascais, Portugal (2006)

7. Hagiwara, M., Akagi, H.: PWM Control and Experiment of Modular Multilevel Converters. In: IEEE Power Electronic Specialist Conference, Rhodes, pp. 154-161 (2008)

8. Silva, J.F., Pinto, S.F.: Control Methods for Switching Power Converters. In: Rashid, M.H. (ed.) Power Electronics Handbook, 2nd edn., USA, ch. 34, pp. 935-998, 1172. Academic Press, Elsevier (2007) ISBN 13:978-0-12- 088479-7, ISBN 10:0-12-088479-8

9. Encarnação, L., Silva, J.F.: Sliding Condition Based Sliding Mode Modulators for Multilevel Power Converters. In: 35th Annual Conference of the IEEE Industrial Electronics Society - IECON Porto, Portugal (2009) 